Artykuly / Articles

Инесса Морозова

ORCID: 0000-0002-3566-331X

inesmorozova@bk.ru

Национальная академия наук Бемаруси

Институт фимософии

Бемарусь

\title{
Субъектность и креативность старшего поколения в современном обществе
}

\author{
Subjectivity and creativity of the older generation \\ in modern society \\ Podmiotowość i kreatywność starszego pokolenia \\ we współczesnym społeczeństwie
}

DOI: 10.34739/doc.2020.17.09

\begin{abstract}
Аннотация: В статье представлен анализ субъектности и креативности представителей старшего поколения. Утверждается, что реализация креативного подхода в профессиональной и иной деятельности пожимых Аюдей способствует максимальному продмению их независимой и активной жизни. Рассматриваются проблемы дискриминации пожилого человека по возрасту, вопросы стереотипного восприятия старшего поколения.
\end{abstract}

КАючевые слова: пожилой человек, старшее поколение, субъектность, креативность, общество, стереотипы

Abstract: The article presents an analysis of the subjectivity and creativity of older representatives in modern society. It is argued that the implementation of a creative approach in professional and other activities contributes to the maximum extension of their independent and active life. The problems of discrimination of an elderly person by age, issues of stereotyped perception of the older generation are touched upon in the article.

Keywords: elderly person, older generation, subjectivity, creativity, society, stereotypes 
Abstrakt: W artykule przedstawiono analizę podmiotowości i kreatywności przedstawicieli starszego pokolenia. Twierdzi się, że realizacja kreatywnego podejścia w działalności zawodowej seniorów i przyczynia się do maksymalnego wydłużenia ich samodzielnego oraz aktywnego życia. Omówiono problemy dyskryminacji osoby starszej ze względu na wiek i kwestie stereotypowego postrzegania starszego pokolenia.

Słowa kluczowe: seniorzy, wiek senioralny, starsze pokolenie, podmiotowość, kreatywność, społeczeństwo, stereotypy

В современной Бемаруси в последние годы наблюдается общемировая тенденция старения населения. Основными его причинами явцяются падение рождаемости, увеличение продолжительности жизни в старших возрастных группах, повышение качества жизни населения, а также законодатемьное увеличение возраста выхода на пенсию в большинстве стран мира. Число жителей старшего возраста планеты растет со скоростью 3\% в год. По данным переписи населения 2019 г., в республике проживало более 2,1 млн граждан в возрасте старше 60 мет. В Бемаруси, по прогнозам, уже к середине века домя миц старше 65 мет достигнет четверти жителей страны ${ }^{1}$.

Нужно отметить, что проблемы старения и субъектности старшего поколения в последнее время находятся в зоне пристального научного внимания исследователей, рассматривающих пожилого человека как мичность, имеющую значительный человеческий потенциал, и отмечающих, что при нормальном старении домжны поддерживаться ее социальные контакты и активность. Аичность домжна сохранять те же желания и потребности, что и в среднем возрасте. Старение - это борьба за сохранение среднего возраста, новый стиль жизни, побуждающий $\mathrm{k}$ постоянной активности, $\mathrm{k}$ чувству ответственности за собственную мичность ${ }^{2}$. Такая ситуация обуславливает не только формирование новых потребностей

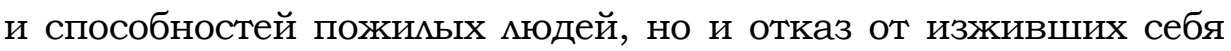
представлений о старости. Проблема ценности старшего

1 Беларусь стареет и планирует адаптировать $\kappa$ этому повестку дня, https://neg.by/novosti/otkrytj/belarus-stareet, (дата доступа: 29.10.2020).

2 О.О. Голуб, Развитие творческой активности у пожильх людей, [в:] Пожилой человек в изменяюшемся мире, ред. А.В. Северин, Брест 2020, с. 12. 
возраста и идеалов пожилых становится существенным элементом психологического киимата общества, создающего психологический комфорт или дискомфорт пожилых ${ }^{3}$. Но еще более важным фактором, определяющим развитие пожилого человека, является то, что в условиях современного

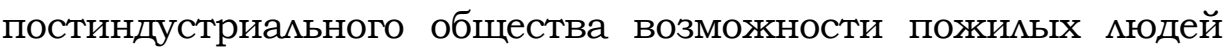
увеличиваются не только в сфере работы, но и в сфере досуга, межличностных отношений. Соответственно, периодизация по паспортному возрасту становится неудовлетворитемьной дия описания особенностей развития пожилого человека. Появимись периодизации, основанные прежде всего на социальных и психологических критериях ${ }^{4}$.

Существует последний классификационный вариант возраста, отражающий следующие позиции: до 45 мет считается периодом момодости; от 45 до 59 мет - средний возраст; от 60 до 74 мет - период пожилого возраста; от 75 до 89 мет - старость; от 90 мет - период домгожитецьства. При этом, следует отметить, что современная психология развития утверждает, что невозможно точно указать границы стадий развития взрослых известно, в возрастной социологии принято акцентироваться не на хронологическом возрасте, а на социальных экспектациях и культурных ценностях, с помощью которых индивид обозначается как "молодой", "средних мет" или "пожилой»б. По мнению ученых, социологический критерий является более правимьным применительно к предпенсионному и пенсионному возрасту. В исследовательской практике неоднократно отмечалось, что человек выстраивает свою жизнь, формирует стратегию и стиль жизни, реализуя свой субъектный потенциал, связанный с жизненными установками, ценностными ориентациями. Субъектность означает определение себя

\footnotetext{
3 Е.В. Щанина, Интеграиия пожилых людей в современный соииум, „Известия высших учебных заведений. Поволжский регион. Общественные науки” 2015, № 1 , c. 150 .

4 О.В. Оконешникова, Типь соииальной субъектности в пожилом возрасте, „Вестник СПбГУ. Сер.12” 2011, Вып. 3, с. 111.

5 Ibidem.

6 В. Анурин, Некоторые проблемы соииологии старости, [в:] Психология старости и старения. Хрестоматия, ред. О.В. Краснова, А.Г. Аидерс, Москва 2003, c. 87.
} 
в системе ценностей и осмысление своей жизни во временном аспекте (прошиое - настоящее - будущее). Тем более значимо и важно, что человек старшего возраста демонстрирует способность самостоятельно принимать решение, демать выбор, то есть проявлять субъектность. Субъектность выражает отношение человека к себе как к деятелю и проявляется в совершении поступков ${ }^{7}$.

При этом старение населения в мире отражает не только увеличение удельного веса пожилых миц на земле, но и рост их социальной значимости в обществе, возможности влиять на общественные процессы. В связи с этим особую актуальность приобретают вопросы о том, как вписываются пожилые мюди в контекст современной действительности. Период поздней взрослости и социально, и хронологически совпадает с выходом человека на пенсию. Человек теряет важную социальную роль и значимое место в обществе. Сужается круг общения человека, что в свою очередь приводит к изменениям в его мичности. Естественно, что для периода поздней зрелости характерны специфические изменения в системе социальных отношений. Человек как субъект собственной деятельности направляет свою активность не только на мир вещей и мюдей, но и прежде всего на себя. Субъект деятельности в своей развитой форме способен должным образом осознавать сущность собственных психических качеств и сознательно ставить перед собой цель, что способствует осуществлению развития психических особенностей. Уровень субъектности растет благодаря саморегуляции поведения мичности. Быть субъектом при саморегуляции поведения означает придавать мичностный смысл общечеловеческим и конкретно индивидуальным ценностям ${ }^{8}$.

Важнейшим условием дмя характеристики пожилого возраста является наличие или отсутствие работы и отношение к трудовой активности. Но это не единственное условие дмя социальной активности человека. Другими важными условиями

7 О.В. Оконешникова, Типы соииальной субъектности..., с. 111.

8 Т.В. Кириченко, Особенности саморегуляиии поведения людей пожилого возраста в современном мире, [в:] Пожилой человек в изменяюшемся мире, ред. А.В. Северин, Брест 2020, с. 23. 
является фризическое здоровье (и сопровождающая его активность), а также семейное положение пожилого чемовека (наличие супруга, детей и опыта брачных отношений, состав семьи и особенности коммуникации) ${ }^{9}$. Социальная субъектность в пожилом возрасте означает самоопределение субъекта не только относительно самого себя, но и самоопределение относительно важнейших сфер социальной жизни: работа, семья, другие мюди, социальные институты.

Пенсионный возраст характеризуется тем, что он позволяет старшему поколению строить и находить новые жизненные перспективы вне сферы профессионального труда. Дия одних таковыми становятся хобби, путешествия, дия других - домашний труд в пользу семьи, воспитание внуков. По убеждению Э. Эриксона, для этой последней фазы зрелости характерно суммирование, интеграция и оценка всех прошлых стадий развития эго. На основании изучения историй многих пожилых мюдей, Э. Эриксон демает вывод о том, что "пожилые мюди домжны участвовать в таких видах деятемьности, как воспитание внуков, политика, оздоровительные физкультурные программы, если они хотят сохранить жизнеспособность в преддверии снижения физических и психических способностей»10. Однако работающие бабушки и дедушки такие же характерные социальные типы, как работающие родитеми, материальная независимость от детей, высокий жизненный тонус и стремление $\mathrm{K}$ независимости пожимых характерные черты современного образа жизни семьи. У многих пенсионеров стремление продолжать работу порой симьнее, чем желание своим участием оказывать помощь детям и их семьям. Социальные параметры пожилых вкцючают их социальный статус, место в современном обществе, в различных социальных системах, общностях, в собственной семье, взаимоотношения

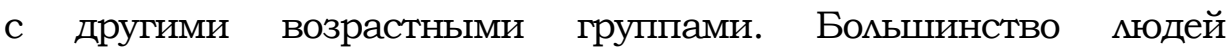
в пенсионном возрасте сохраняют хорошую работоспособность, ответственность, компетентность, интемлектуамьный потенциа ${ }^{11}$.

\footnotetext{
9 О.В. Оконешникова, Типь соииальной субъектности..., с. 112.

10 А. Хьеми, Д. Зиглер, Теории личности, Санкт-Петербург 1999.

11 Е.В. Щанина, Интеграиия пожильх людей..., с. 151.
} 
В этой связи становится достаточно актуальным вопрос вовлечения (удержания) мюдей пожилого возраста в социальнотрудовые отношения. Важно отметить, что на данном этапе развития все более возрастает социальный запрос на профессиональный ресурс данной группы мюдей современного общества. В докладе II Всемирной ассамблеи ООН по проблемам старения особо отмечается роль граждан третьего возраста в общественном развитии, и в связи с этим указывается, что изменение демографической структуры ставит все общества перед необходимостью содействовать расширению возможностей пожильх Аюдей к самореализации ${ }^{12}$.

Необходимость сохранения активной жизни в пожилом возрасте явцяется одной из актуальных проблем современного белорусского общества и имеет общегосударственное значение, принимая во внимание происходящие трансформации, влекущие за собой существенные изменения пенсионной политики, связанные с увеличением возраста выхода на пенсию. Существует ряд государственных программ (Государственная программа о социальной защите и содействии занятости населения на 2016-2020 годы; Государственная программа «Здоровье народа и демографическая безопасность Республики Беларусь" на 2016-2020 годы), нацеленных на расширение возможностей реализации социальной активности представителей старшего поколения (реализации их субъектности), эфрфективного использования их огромного профессионального потенциала, востребованного в так называемой "серебряной экономике" ("седой рынок", то есть рынок возможностей дия пожилых мюдей). Так, по данным Белстата, в возрастной структуре работников отечественных организаций - 8,7\% мюдей старше 60 мет. Больше всего пожильх работников в научной сфере - $22,6 \%$ в общем числе занятых исследованиями и научными разработками. В сфере недвижимости задействовано $15,9 \%$ работников старше 60 мет, в сфере услуг - 14,3\%, в образовании - 13,3\%, меньше всего

12 М.Ю. Уварова, Е.А. Кедярова, $K$ проблеме изучения проявлений геронтологического эйджизма в современном обществе, „Известия Иркутского государственного университета" 2015, Т. 14, с. 74. 
пожильх работников в IT-сфере $(6,4 \%)$ и сфере страхования и финансов $-2,9 \% 13$.

"Рынок труда нуждается в квалифицированных работниках. Поэтому сегодня законодательством не установлено никаких ограничений и рынок труда заинтересован, чтобы мюди старших возрастов не покидали его. Такая политика будет реализовываться и в дальнейшем", - сообщил начальник управления политики занятости Минтруда и соцзащиты О. Токун. Министр труда и соцзащиты И. Костевич сообщила о том, что из тех, кто достиг пенсионного возраста, работать после назначения пенсии продолжают почти 23\%, то есть 485 тысяч человек. В нашей стране разрешено получать и зарплату, и пенсию. Причем размер пенсии ограничивается незначительно и только у части пенсионеров, при этом максимальные размеры пенсий не ограничены ${ }^{14}$.

Однако отношение общества к пожилым мюдям порой неоднозначно, существуют явления их дискриминации (зачастую скрытой), поэтому давно назрела необходимость серьезного преодоления стереотипного восприятия жизненных стратегий старших поколений, понимаемых как недостаточно эффективные и ущербные, мишенные жизнеспособности. Отдельные стереотипные установки молодежи, доминантами которых являются мизантропия и моральный нигилизм, отражают восприятие миц пожилого возраста с позиций Аичностного неприятия и скепсиса. Феномен старения (поздняя взрослость) во все времена представлял сложную мировоззренческую проблему. Наряду с положительными оценками всегда присутствовали и отрицательные. С одной стороны, старость олицетворяла мудрость и правильно прожитую жизнь. С другой стороны, проблемы, обусловленные угасанием жизненных сил человека, вызывали негативные

131 октября - Международный день пожильх людей, https://neg.by/novosti/ otkrytj/1-oktyabrya---mezhdunarodnyj-den-pozhilyh-lyudej-0, (дата доступа: 29.10.2020).

14 Т. Чернухо, Почему в Беларуси становится все меньше работаюших пенсионеров, https://www.kp.by/daily/27046/4111615/, (дата доступа: 29.10.2020). 
реакции ${ }^{15}$. В современном мире установилось двойственное отношение к старению. С одной стороны, в некоторых странах все еще живы геронтофильные установки по отношению к старости, когда пожилые почитаются и в некоторой степени даже обожествляются. Но эти установки ослабевают, набирают силу противоположные - геронтофобные взгляды. Общество, ориентированное на молодых, которое на самом деме с каждым годом становится все более обществом стариков, все больше и больше стремится к молодости и закрывает глаза на существование пожилых. Можно сделать вывод о противоречивой картине образа пожилого человека, представленного в обыденном сознании ${ }^{16}$.

Изучение стереотипных установок о пожилых работниках свидетельствует о том, что наблюдающиеся сегодня в сфере социально-трудовых отношений тенденции крайне противоречивы. Например, основной проблемой в сфере социально-трудовых отношений в современной России является жесткая конкуренция поколений на рынке труда. По мнению экспертов, все возрастные группы, так или иначе, сталкиваются с дискриминацией на рынке труда, но по разным причинам. Основные трудовые риски молодежи в данном случае связаны с отсутствием опыта работы по специальности, низким качеством образования, высокими зарплатными и карьернодолжностными требованиями. Права старшей возрастной группы в сфере социально-трудовых отношений ущемляются наиболее часто. Сегодня представители старшей возрастной группы вытесняются с рынка труда в силу различных причин: давцения молодежи, стереотипов работодателей, несоответствия современным требованиям к работнику (в частности, в плане компьютерной грамотности), потребности в особом режиме и интенсивности труда из-за состояния здоровья 17.

15 М.М. Старикова, Стереотипь старости и старения, „Вестник Нижегородского университета им. Н.И. Аобачевского. Сер. Социальные науки" 2011, № 2 (22), с. 43.

16 С.А. Ящук, Представление о пожилом человеке в обыденном сознании, [в:] Пожилой человек в изменяюшемся мире, ред. А.В. Северин, Брест 2020, с. 62.

17 С.Г. Максимова, О.Е. Ноянзина, М.М. Максимова, Рынок труда: риски исключения из соииально-трудовых отношений различных поколений 
Исследования стереотипных представмений о работниках старшего возраста, которые сложились в обществе по таким параметрам, как профессиональные навыки и знания, работоспособность и трудолюбие, скорость решения поставленных задач, инициативность и нацеленность на результат, коммуникабельность, умение работать в команде, ответственность и исполнительность свидетельствуют о том, что пожилые работники превосходят своих более молодых комлег по профессиональным навыкам и знаниям, ответственности, исполнительности и трудолюбию. Однако по таким параметрам, как инициативность, скорость решения поставменных задач, работоспособность, пожилые мюди уступают им. По другим же параметрам пожилые мюди ничем не уступают своим комлегам ${ }^{18}$.

Но главным преимуществом пожилых мюдей по сравнению с более молодыми комлегами в трудовой сфере являются профессиональный опыт и знания. Оценивая роль и знания старшего поколения в профессионально-деловой сфере, большинство работодателей и комлег пожильх работников отмечают, что они обладают большим опытом, незаменимы как наставники молодежи, а использование трудового потенциала представителей старшего возраста обеспечивает передачу профессионального опыта молодым работникам ${ }^{19}$. Вполне закономерно, что во многих странах мира серьезно озабочены проблемой передачи опыта, знаний и компетенций от старших поколений к последователям. Так, в США, где проходят Международные конференции и выставки Американского сообщества по тренингам и развитию (ASTD), постоянно обсуждаются вопросы, как наладить взаимодействие между разными поколениями в компаниях дия обмена опытом внутри организаций; снизить разрыв ценностей между ними, как обеспечить преемственность между поколениями, чтобы уход пожилых не повлек за собой потерю уникальных знаний, технологий и отношений. Например, пожильх стараются привлекать как коуч-наставников для более молодых поколений

в стареющем обиестве, „Вестник А^тайского государственного аграрного университета" 2017, № 5, с. 187-189.

18 Е.В. Щанина, Интеграиия пожильх людей..., с. 153.

19 Ibidem, c. 154. 
руководителей для "соединения" ценностных разрывов. В России и странах СНГ также виден рост интереса к взаимодействию поколений, налаживанию связей между ними, подготовки смены, преемников, переформатированию целей - чтобы сделать их понятными для разных поколений ${ }^{20}$.

Поэтому нескучайно невостребованность представителей старших возрастов на рынке труда, по мнению исследователей, в конечном итоге ведет к утрате значительной части человеческого капитала, а конфмиктная ситуация разных возрастных групп населения, обусловленная конкуренцией за рабочие места, может привести к росту социальной напряженности и разобщенности поколений ${ }^{21}$. Эту социальную разобщенность поколений вполне можно преодолеть путем усиления взаимодействия, диалога в самом широком смысле слова между молодежью и старшим поколением. Диалог используется как инструмент согласования взглядов, в соответствии с которыми открываются возможности дАя открытого разговора субъектов, а значит, и поколений. Важная роль здесь принадлежит именно старшему поколению, поскольку именно поздняя зрелость способна всесторонне оценить общую перспективу развития кичности, являясь связующим звеном времен и поколений. В этом случае достигается социально значимый эффект: снижается острота межпоколенного конфликта, который неизбежен в силу различных жизненных условий разных поколений. Однако это и более сложный путь, поскоцьку в контакт вступают носители разного жизненного, культурного опыта, моральных ценностей, мобильности и способностей к адаптации. Поэтому диалог поколений в процессе коммуникации предполагает установление межличностного согласия, способности совместно решать жизненные задачи 22 .

20 Е. Шамис, Беби-бумеры уходят на пенсию: о каких проблемах говорит мир (по материалам конферениии ASTD, США 2009), https://rugenerations.su/ 2009/06/25, (дата доступа: 18.03.2020).

21 С.Г. Максимова, О.Е. Ноянзина, М.М. Максимова, Рынок труда..,, с. 192.

22 Е.А. Бай, Период поздней взрослости: как строить диалог поколений, [в:] Пожилой человек в изменяюшемся мире, ред. А.В. Северин, Брест 2020, с. 4. 
Молодежь также порой испытывает дискриминацию по возрастному признаку на рынке труда, она, как правило, носит скрытый характер (как и в отношении старшего поколения), поэтому решение такой жизненной задачи этим двум поколениям необходимо осуществлять совместно. Например, Э. Гидденс принимает точку зрения М. Янга и Т. Шамлера, создавших уникальную книгу Жизнь после работы: Пришествие Безвозрастного Обиества, согласно которой, молодые мюди и старшее поколение должны образовать альянс, «чтобы вырваться из плена прикрепления возрастным группам и создать безвозрастное общество. Они станут пионерами не только относительно своей социальной позиции, но и по отношению $\mathrm{k}$ большинству работающего населения» 23 . Гидденс полностью разделяет мнение авторов о том, что в мире возраст превратился в орудие угнетения, служащее дия того, чтобы загонять мюдей в тесные рамки

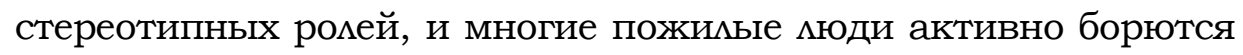
с подобным отношением, ищут новые сферы деятельности и способы самореализации. Они бросают вызов обществу, ставшему заложником у возраста. В современных обществах и молодежь, и старики оцениваются прежде всего по возрасту, а их занятия, мичностные и индивидуальные характеристики имеют второстепенное значение ${ }^{24}$. Сейчас следует минимизировать риски, связанные с проявлениями эйджизма

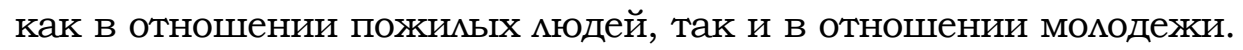
Необходимо принять комплекс поощрительных мер для организаций и предприятий, в которых соблюдается баланс межвозрастного присутствия. Например, предлагается ввести налоговые $ь$ ьготы и субсидирование предприятий и организаций, которые принимают на работу пожимых $\Lambda и ц^{25}$.

Необходимо понимать, что в современном социуме существует не только молодежь, сформировавшаяся

\footnotetext{
23 Э. Гидденс, Социология, Москва 2005, с. 564.

24 Ibidem.

25 И. Калабихина, Н. Красовская, Н. Каммыкова, Демографическое старение в Республике Беларусъ: вызовы и новые возможности: Аналитический обзор. Проект "Поддержка реализаиии Наииональной программы демографической безопасности Республики Беларусъ", Минск 2018, с. 5.
} 
в компьютерную эпоху (поколения $Z$ и А^ьфа), но и поколение представителей поздней зрелости, которое существенно отличается от своих предшественников, поскольку серьезно трансформировалось в результате влияния происходящих социальных изменений за последние четверть века. Главной отличительной особенностью является тот факт, что при наличии константных качественных характеристик, присущих позднему зрелому возрасту и обладающих якобы способностью тормозить восприятие всего нового и прогрессивного, представители старшего поколения достаточно мегко и вполне комфортно ощущают себя с вновь приобретенными в современном обществе (гибкость, стрессоустойчивость, предприимчивость, компьютерная и финансовая грамотность и т.д.), что свидетельствует о хорошей адаптационной способности представителей старшего поколения к изменяющимся социальным условиям. Например, по данным Белстата, весьма показательно, что Интернет освоили 41,3\% пожилых (2,3\% в 2010 году). При этом 62,4\% пользователей входят в сеть ежедневно. Среди пожилых мюдей, проживающих в городах и поселках городского типа, сетью Интернет в 2019 г. пользовались 47\%, среди пожильх сельчан - 27,2\%26.

Исследователи неоднократно подчеркивали, что существенный признак новой социальной реальности начала третьего тысячелетия связан с глобализацией информационных процессов, информатизацией социального пространства, компьютеризацией разных сфер человеческой деятельности. Успешная адаптация старшего поколения в пространстве информатизации имеет большое значение для организации их нормальной жизнедеятельности, развития и самореализации, позволяет им не только не выпадать из жизни общества, но и, используя виртуальные информационные ресурсы, оставаться ее активными субъектами, включаться в информационносоциализирующий процесс 27 . Повседневная жизнь все больше

261 октября - Международный день пожильх...

27 Н.И. Нескоромных, А.М. Мамадалиев, Стратегии адаптивного поведения лии пожилого возраста в интернет-пространстве, „Медиаобразование” 2017, № 1 , c. 167. 
виртуализируется, а освоение новых цифровых возможностей уменьшает неравенство между поколениями во всех сферах жизнедеятельности. Не пользуясь ими, не "встраиваясь" в цифровой мир, человек рискует многим - от потери работы, до общего понижения качества жизни ${ }^{28}$.

Например, пожилые пользователи Интернета признают его роль как мультиресурса со своими достоинствами и недостатками, необходимого дмя успешной адаптации в современном социуме и социальной интеграции, для умучшения качества жизни; стремятся с помощью информационнокоммуникационных технологий и онлайн-активности решить свои жизненные проблемы (поддержать или восстановить круг общения, адаптироваться к меняющимся жизненным условиям, улучшить психологическое, эмоциональное состояние и др.) ${ }^{29}$.

$\mathrm{K}$ негативным проявлениям использования Интернета исследователи относят частичное изменение формы мышления: 4) актуализация новых страхов и рисков (получение можной или нежелательной информации, заражение компьютера вредоносными вирусами и программами, навязывание знакомства, недобросовестное использование персональных данных, потеря денег без приобретения товара или услуги) ${ }^{30}$. Исследователей настораживает подобная ситуация в мире, например, в польских исследованиях указывается, что, невзирая на многочисленные возможности развития, предлагаемые современным компьютеризированным миром и обществом

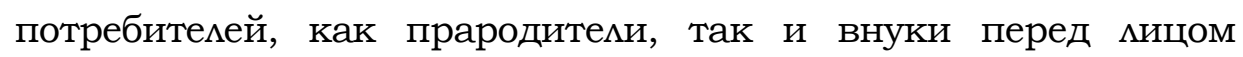
сложной и постоянно меняющейся реальности часто чувствуют себя дезориентированными, непонятыми и потерянными, "и оба возраста, старость и юность, явцяются периодом кризисов, конструирования или повторного открытия концепции самого себя. Молодое поколение стремится к новым попыткам

28 О.А. Алексеева, О.Ю. Бестужева, О.Н. Вершинская, А.Ю. Галюжин, Е.Е. Скворцова, Новые возможности и риски потребления электронных услуг людъми старшего возраста, „Народонаселение” 2019, Т. 22, № 1, с. 132.

29 Н.И. Нескоромных, А.М. Мамадалиев, Стратегии адаптивного поведения..., c. 167.

30 О.А. Алексеева, О.Ю. Бестужева, О.Н. Вершинская, А.Ю. Галюжин, Е.Е. Скворцова, Новые возможности..., с. 134. 
идентифицировать себя, в то время как старшее поколение, которое находится в фазе между продуктивностью и стагнацией, пытается сосредоточить свою заботу на чем-то или на ком-то. Поэтому существует потребность в сотрудничестве поколений»31.

Однако важно отметить позитивные особенности адаптивного поведения миц пожилого возраста в интернетпространстве. Так, мобимьность, мегкость вхождения в киберпространство способствуют относительно безболезненному преодолению адаптивных барьеров (например, утраченные социальные связи с референтным трудовым и социально-профессиональным окружением восстанавливаются за счет возможности передать жизненный опыт более молодому поколению через онлайн-консультирование по профессиональным и экзистенциальным вопросам; нарушенные межпоколенческие взаимодействия восстанавливаются, например, через общение по скайпу) и высокому уровню адаптации в современном информационном пространстве 32 .

Bсе это способствует развитию обучения (самообразования) у представителей старшего поколения. Проблемы социальной адаптации пожилых Аюдей в посттрудовой период являются предметом пристального внимания правительственных органов. Успешное функционирование в республике Университета третьего возраста, Университета Золотого века, Центра общественной активности позволяют представителям старшего поколения приобретать новые профессиональные и деловые навыки и умения (курсы иностранных языков, компьютерной, правовой, финансовой грамотности), развивать креативность (активно использовать Интернет, социальные сети, блоги, демонстрировать мастер-классы, фотопозирование, копирайтерство и т.п.), а также активно участвовать в волонтерском движении (педагогическое, экологическое направления и пр.).

31 Т.С. Онискевич, Роль прародителей в соииализаиии молодежки (по материалам зарубежных исследований), [в:] Пожилой человек в изменяющемся мире, ред. А.В. Северин, Брест 2020, с. 44-45.

32 Н.И. Нескоромных, А.М. Мамадалиев, Стратегии адаптивного поведения..., c. $167-168$. 
Креативность проникает практически во все сферы жизнедеятемьности, основывается на повседневных способностях, таких как мышление, восприятие, память и рефлективная самокритика. Исследователи выделяют основные мотивационные факторы, побуждающие к креативности в старшей возрастной группе: настойчивость, дисциплинированность и преданность июбимому делу на протяжении домгих мет. Не менее значимыми оказались объем и характер полученного образования ${ }^{33}$. Д. Рубин утверждает, что «креативность дает мюдям возможность ощутить свой

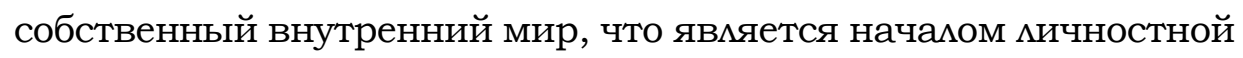
трансформации", а "(..) творческое пространство дает человеку возможность пойти на риск без осуждения и оценки»34. В процессе творчества человек не стремится отдалиться от реальности, наоборот, следует установить прочную связь между творческим процессом и нашей реальной жизнью.

Важно отметить, что сотрудники, которые отказались выходить на пенсию и продомжили трудиться в обычном режиме, смогми сохранить свои творческие способности вплоть до позднего возраста Это дает исследователям определенные основания полагать, что главным фактором, влияющим на снижение творческой активности в зрелом возрасте, является не ухудшение физиологических функций, а непосредственный выход из профессии в пенсионном возрасте. Другим фактором, по мнению ряда ученых, является необходимость сотрудничества с другими мюдьми в процессе творческой деятельности. Также им приходимось одновременно работать над несколькими проблемами, что заставляло постоянно переключаться между ними и приводимо к нахождению оригинальных решений. Представители старшего поколения склонны испытывать большие затруднения именно на этапе генерирования идей, поскомьку происходят возрастные ухудшения процессов, составцяющих его основу, однако они

33 А.А. Попель, Обусловленность креативности возрастным фактором, „Вестник Пермского национального исследовательского политехнического университета. Социально-экономические науки” 2017, № 3, с. 142.

34 J.A. Rubin, Introduction to art therapy: sources and resources, New York 2009, c. 29 . 
имеют гораздо больший жизненный и профессиональный опыт, что дает им возможность превзойти своих более молодых оппонентов в части интуиции и мудрости, необходимой дмя нахождения оригинального решения ${ }^{35}$.

Сегодня в отношении креативности многие исследователи выделяют и такие черты: уверенность, независимость суждений, гибкость, склонность к риску, проницательность и интуиция, открытость и восприимчивость и др. Это особенно актуально на современном этапе развития экономической ситуации, когда предпринимательская деятельность наиболее востребована в обществе, в том числе среди представителей старшего возраста. Учитывая взаимосвязь креативности с предпринимательской сферой, исследователи отмечают концепцию экономической динамики и циклов Й. Шумпетера, который побудительным мотивом к поиску и внедрению новых комбинаций рассматривал прибыль. По его мнению, определяющую роль играет не конкуренция цен или качества, а конкуренция новых продуктов, технологий, организационных фором ${ }^{36}$. Центральным субъектом в процессе изменений внутри системы явцяется предприниматель, который внедряет новшества в периоды спокойствия и равновесия. А в условиях рыночной экономики предприниматель-новатор выступает движущей симой изменений. Предприниматель имеет скмонность к творчеству, созиданию и инновациям; стремится к расширению своей деятельности; обладает такими чертами, как расчетливость, аналитический стиль.

Реализация креативного подхода в профессиональной и иной деятельности, учитывая изменения статуса пожилых мюдей, способствует максимальному продлению их независимой и активной жизни, пересмотру ценностных ориентиров, самого образа жизни и общения, а также устранению различных затруднений как в социально-бытовой, так и в психологической сфрерах. Все это приводит $\mathrm{K}$ активному включению

35 А.А. Попель, Обусловленность креативности..., с. 144.

36 Й. Шумпетер, Теория экономического развития (Исследование предпринимательской прибыли, капитала, кредита, проиента и иикла конъюнктуры), Москва 1982. 
представителей старшего возраста в экономику и социальную жизнь страны, что в свою очередь обеспечивает усиление взаимодействия поколений. При этом необходимо учитывать желание молодежи выстраивать эти взаимоотношения на эгалитарной основе, ведь взаимный обмен знаниями, обеспечивающий взаимосоциализацию (существует френомен "обратной" социализации, актуальный в эпоху всеобщей компьютеризации, т.е. модемь, при которой старшее поколение учится у молодых новым ценностям и жизненным нормам), а также отсутствие чрезмерной назидательности и менторства у пожилых, безусловно, будет способствовать гармоничному межпоколенному взаимодействию, что является одним из важнейших факторов стабильного развития современного общества.

Следует также учитывать серьезные изменения В эмоционально-психологической и нравственной сферах представителей старшего поколения: проблемы со здоровьем, снижение самооценки, ощущение бессодержательности жизни, осознание неизбежности приближения ухода из нее. Этому способствуют стереотипные установки молодежи, отражающие восприятие миц пожилого возраста с позиций ущербности и угасающих способностей, проявление отвращения к старости. Неслучайно Б. Тарнавский подчеркивает особую роль детей в жизни пожилого человека: "важно привить детям это чувство ответственности, заботливости, симпатии к старикам. Потребность помочь, выполнить просьбу должна войти в кодекс нравственности и поведения нашей молодежи»37. Особенно это актуально сейчас в условиях пандемической ситуации, когда возрастает необходимость в оказании всесторонней помощи пожилым Аюдям со стороны близких родственников и представителей общественных организаций, что активно осуществляется на данный момент в нашей стране (работа социальных служб, молодежных организаций, волонтерского сообщества и др.).

37 Ю.Б. Тарнавский, Чтобы осень была золотой (как сохранить психическое здоровъе в старости), Москва 1998, с. 94. 
Сегодня Аюди старших возрастов в контексте устойчивого социального развития рассматриваются мировым сообществом как позитивный фактор, а не бремя. Этот подход отражен в Международном (Венском) плане действий по проблемам старения. На Западе на протяжении ряда мет существует своеобразный культ поздней взрослости, третьего возраста. Актуализируются проекты, ориентированные на услуги дия пожилых. В нашей стране рынок продуктов и услуг дмя старшего поколения развивается медменно, он нуждается в развитии, принимая во внимание перспективность этого направления.

По убеждению специалистов, демографическое старение населения в качестве последствий неизбежно приведет к изменению социальных стереотипов как с их содержательной, так и с оценочной стороны. За счет новых стратегий и смыслов жизни в период поздней зрелости в сочетании с ростом доли пожильх мюдей в структуре населения увеличится и их "социальная сила" и, "вероятно, представители старшего поколения из объектов социальных стереотипов превратятся в субъектов социального конструирования смыслов процесса старения, являющегося естественным дия всех мюдей. Поэтому то, как мы представляем пожилых и старых мюдей, является оценкой нашего собственного будущего»38.

Также необходимо исходить из того, что старение не является проблемой, а представцяет собой особое качество современного состояния общества, новый уклад жизни. Международные документы по проблемам старения в мире (Венский и Мадридский международные планы действий по проблемам старения; Хартия пожилых мюдей и т.д.) отражают всестороннее осмысление этого феномена, вцияние которого ощущается как на местном, так и на глобальном уровнях, охватывает разные сферы общества. Старшее поколение золотой фонд мюбой страны, и глубинное понимание этого очевидного неоспоримого факта будет способствовать устойчивому и гармоничному развитию социума.

38 М.М. Старикова, Стереотипы старости..., с. 50. 


\section{Бибииография / References}

1 oktjabrja - Meždunarodnŷj den' požylŷch ljudej, https://neg.by/ novosti/otkrytj/1-oktyabrya-mezhdunarodnyj-den-pozhilyhlyudej-0, (data dostupa: 29.10.2020), [1 октября Международный день пожильх людей, https://neg.by/ novosti/otkrytj/ 1-oktyabrya-mezhdunarodnyj-den-pozhilyhlyudej-0, (дата доступа: 29.10.2020)].

Alekseeva O.A., Bestuževa O.Ju, Veršynskaja O.N, Haljužyn A. Ju, Skvorcova E.E., Novŷe vozmožnosty y rysky potreblenyja эlektronnŷchusluh ljud'my staršeho vozrasta, "Narodonaselenye” 2019, Т. 22, № 1, [Алексеева О.А., Бестужева О.Ю., Вершинская О.Н., Галюжин А.Ю., Скворцова Е.Е., Новые возможности и риски потребления электронных услуг людьии старшего возраста, „Народонасемение” 2019, Т. 22, № 1].

Anuryn V., Nekotorŷe problemŷ socyolohyy starosty, [v:] Psycholohyja starosty y starenyja. Chrestomatyja, red. O.V. Krasnova, A.H. Lyders, Moskva 2003, [Анурин В., Некоторые проблемы соииологии старости, [в:] Психология старости и старения. Хрестоматия, ред. О.В. Краснова, А.Г. Аидерс, Москва 2003].

Baj E.A., Peryod pozdnej vzroslosty: kak stroyt' dyaloh pokolenyj, [v:] Požyloj čelovek v yzmenjajuščemsja myre, red. A.V. Severyn, Brest 2020, [Бай Е.А., Период поздней взрослости: как строить диалог поколений, [в:] Пожилой человек в изменяющемся мире, ред. А.В. Северин, Брест 2020].

Belarus' stareet yplanyruet adaptyrovat' $k$ эtomu povestku dnja, https://neg.by/novosti/otkrytj/belarus-stareet, (data dostupa: 29.10.2020), [Беларусь стареет и планирует адаптировать $\kappa$ этому повестку дня, https://neg.by/novosti/otkrytj/belarusstareet, (дата доступа: 29.10.2020)].

Ch'ell L., Zyhler D., Teoryy lyčnosty, Sankt-Peterburg 1999, [Хьем $\Lambda$. , Зигмер Д., Теории личности, Санкт-Петербург 1999].

Černucho T., Počemu v Belarusy stanovytsja vse men'še rabotajuščych pensyonerov, https://www.kp.by/daily/27046/4111615/, (data dostupa: 29.10.2020), [Чернухо Т., Почему в Беларуси становится все меньше работаюших пенсионеров, https://www.kp.by/daily/27046/4111615/, (дата доступа: 29.10.2020)].

Holub O.O., Razvytye tvorčeskoj aktyvnosty u požylŷch ljudej, [v:] Požyloj čelovek v yzmenjajuščmsja myre, red. A.V. Severyn, Brest 2020. [Голуб О.О., Развитие творческой активности у пожильх 
людей, [в:] Пожилой человек в изменяюшемся мире, ред. А.В. Северин, Брест 2020].

Hyddens Э., Socyolohyja, Moskva 2005, [Гидденс Э., Соииология, Москва 2005].

Jaščuk S.L., Predstavlenye o požylom čeloveke v obŷdennom soznanyy, [v:] Požyloj čelovek $v$ yzmenjajuščemsja myre, red. A.V. Severyn, Brest 2020, [Ящук С.А., Представление о пожилом человеке в обыденном сознании, [в:] Пожилой человек в изменяюшемся мире, ред. А.В. Северин, Брест 2020].

Kalabychyna Y., Krasovskaja N., Kalmŷkova N., Demohrafyčeskoe starenye $v$ Respublyke Belarus': vŷzovŷ y novŷe vozmožnosty: Analytyčeskyj obzor. Proekt "Podderžka realyzacyy Nacyonal'noj prohrammŷy demohrafyčeskoj bezopasnosty Respublykybelarus'", Minsk 2018, [Калабихина И., Красовская Н., Каммыкова Н., Демографическое старение в Республике Беларусъ: вызовы и новые возможности: Аналитический обзор. Проект "Поддержка реализаиии Национальной програмиь демографической безопасности Республики Беларусъ", Минск 2018].

Kyryčenko T.V., Osobennosty samorehuljacyy povedenyja ljudej požyloho vozrasta $v$ sovremennom myre, [v:] Požyloj čelovek $v$ yzmenjajuščemsja myre, red. A.V. Severyn, Brest 2020, [Кириченко Т.В., Особенности саморегуляиии поведения людей пожилого возраста в современном мире, [в:] Пожилой человек в изменяюшемся мире, ред. А.В. Северин, Брест 2020].

Maksymova S.H., Nojanzyna O.E., Maksymova M.M., Rŷnok truda: rysky ysključenyja yz socyal'no-trudovŷch otnošenyj razlyčnŷch pokolenyj vstarejuščem obščestve, „Vestnyk Altajskoho hosudarstvennoho ahrarnoho unyversyteta" 2017, № 5, [Максимова С.Г., Ноянзина О.Е., Максимова М.М., Рынок труда: риски исключения из соииально-трудовых отношений различных поколений в стареющем обществе, „Вестник А^тайского государственного аграрного университета" 2017, № 5].

Neskoromnŷch N.Y., Mamadalyev A.M., Stratehyy adaptyvnoho povedenyja lyc požyloho vozrasta $v$ ynternet-prostranstve, „Medyaobrazovanye" 2017, № 1, [Нескоромных Н.И., Мамадамиев А.М., Стратегии адаптивного поведения лич пожилого возраста в интернет-пространстве, „Медиаобразование” 2017, № 1].

Okonešnykova O.V., Typŷ socyal'noj sub"ektnosty v požylom vozraste, „Vestnyk SPBHU. Ser.12” 2011, Vŷp. 3, [Оконешникова О.В., 
Типь соииальной субъектности в пожилом возрасте, „Вестник СПбГУ. Сер.12” 2011, Вып. 3].

Onyskevyč T.S., Rol' prarodytelej $v$ socyalyzacyy molodežy (po materyalam zarubežnŷch yssledovanyj), [v:] Požyloj čelovek $v$ yzmenjajuščmsja myre, red. A.V. Severyn, Brest 2020. [Онискевич Т.С., Роль прародителей в соииализаиии молодежи (по материалам зарубежных исследований), [в:] Пожилой человек в изменяюшемся мире, ред. А.В. Северин, Брест 2020].

Popel' A.A., Obuslovlennost' kreatyunosty vozrastnŷm faktorom, „Vestnyk Permskoho nacyonal'noho yssledovatel'skoho polytechnyčeskoho unyversyteta. Socyal'no-эkonomyčeskye nauky" 2017, № 3, [Попемь А.А., Обусловленность креативности возрастным фрактором, „Вестник Пермского национального исследовательского политехнического университета. Социально-экономические науки" 2017, №3].

Rubin J.A., Introduction to art therapy: sources and resources, New York 2009.

Šamys E., Beby-bumerŷ uchodjat na pensyju: o kakychproblemach hovoryt myr (po materyalam konferencyy ASTD, SŠA2009), https://rugenerations.su/2009/06/25, (data dostupa: 18.03.2020), [Шамис Е., Беби-бумерь уходят на пенсию: о каких проблемах говорит мир (по материалам конферениии ASTD, США 2009), https://rugenerations.su/2009/06/25, (дата доступа: 18.03.2020)].

Ščanyna E.V., Yntehracyja požylŷch ljudej v sovremennŷj socyum, "Yzvestyja vŷsšych učebnŷch zavedenyj. Povolžskyj rehyon. Obščestvennŷe nauky" 2015, № 1, [Шанина Е.В., Интеграuия пожилых людей в современный соииум, „Известия высших учебных заведений. Поволжский регион. Общественные науки" 2015, № 1].

Ščanyna E.V., Vostrebovannost' požylŷch ljudej $v$ trudovojsfere $v$ sovremennŷch socyal'no-эkonomyčeskych uslovyjach, „Vlast'” 2017, № 10, [Шанина Е.В., Востребованность пожильх людей в трудовой сфрере в современных соииально-экономических условиях, „Виасть” 2017, № 10].

Starykova M.M., Stereotypŷ starosty y starenyja, „Vestnyk Nyžehorodskoho unyversyteta ym. N.Y.Lobačevskoho. Ser. Socyal'nŷe nauky” 2011, № 2 (22), [Старикова M.M., Стереотипь старости u старения, „Вестник Нижегородского университета им. Н.И. Аобачевского. Сер. Социальные науки” 2011, № 2 (22)]. 
Šumpeter J., Teoryja эkonomyčeskoho razvytyja Yssledovanye predprynymatel'skoj prybŷly, kapytala, kredyta, procenta y cykla kon"junkturŷ), Moskva 1982, [Шумпетер Й., Теория экономического развития (Исследование предпринимательской прибыли, капитала, кредита, проиента и иикла конъюнктуры), Москва 1982].

Tarnavskyj Ju.B., Čtobŷ osen' bŷla zolotoj (kaksochranyt' psychyčeskoe zdorov'e v starosty), Moskva 1998, [Тарнавский Ю.Б., Чтобы осень бъла золотой (как сохранить психическое здоровье в старости), Москва 1998].

Uvarova M.Ju., Kedjarova E.A., $K$ probleme yzučenyjaprojavlenyj herontolohyčeskoho эjdžyzma $v$ sovremennom obščestue, „Yzvestyja Yrkutskoho hosudarstvennoho unyversyteta” 2015, Т. 14, [Уварова М.Ю., Кедярова Е.А., $K$ проблеме изучения проявлений геронтологического эйджизма в современном обществе, „Известия Иркутского государственного университета" 2015, Т. 14]. 